
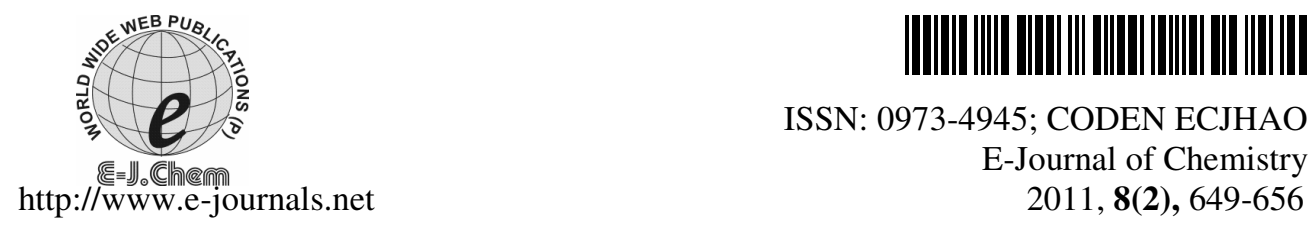

ISSN: 0973-4945; CODEN ECJHAO

E-Journal of Chemistry $2011, \mathbf{8 ( 2 )}, 649-656$

\title{
Malachite Green Dye Removal Using the Seaweed Enteromorpha
}

\author{
R.JAYARAJ ${ }^{\S}$, M. CHANDRA MOHAN, P. MARTIN DEVA PRASATH ${ }^{\S *}$ \\ and T. HIDHAYATHULLAH KHAN \\ ${ }^{\S} \mathrm{PG}$ and Research Department of Chemistry \\ TBML College, Porayar - 609307, Nagapattinam, Tamilnadu, India \\ PG and Research Department of Chemistry \\ Khadir Mohideen College Adirampattinam - 614 701, Tamilnadu, India \\ martinprasath@rediffmail.com
}

Received 9 September 2010; Revised 9 November 2010; Accepted 11 November 2010

\begin{abstract}
Malachite green adsorption from an aqueous solution onto activated Enteromorpha carbon has been studied experimentally using batch adsorption method. Adsorption kinetics and equilibrium were investigated as a function of initial dye concentration, $\mathrm{pH}$, contact time and adsorbent dosage. Kinetics studies indicated that the adsorption followed pseudo second order reaction. Equilibrium data was analyzed using Langmuir and Freundlich isotherm models. The adsorption capacity of Enteromorpha was found to be $94.74 \%$. On the basis of experimental results and the model parameters, it can be inferred that the carbonaceous Enteromorpha is effective for the removal of malachite green from aqueous solution.
\end{abstract}

Keywords: Adsorption, Enteromorpha, Activated carbon, Malachite green dye, Kinetics, Equilibrium.

\section{Introduction}

Dyes normally have a complex aromatic molecular structure which makes them more stable and more difficult to biodegrade ${ }^{1}$. Further dyes have synthetic origin. They are widely used in textiles, paper, rubber, plastics, leather, cosmetics, pharmaceuticals and food industries. At present there are more than 10,000 dyes which are commercially available ${ }^{2}$. Widespread use of dyes often poses pollution problems in the form of coloured waste water discharged into environmental water bodies. It not only affects aesthetic merit but also reduces light penetration and photosynthesis. Also, some dyes are either toxic or mutagenic and carcinogenic ${ }^{3}$. The conventional methods for treating dyes containing waste waters are coagulation and flocculation ${ }^{4}$, oxidation or ozonation ${ }^{5 \& 6}$, membrane separation ${ }^{7}$ and activated carbon adsorption ${ }^{8}$. But these technologies do not show considerable efficiency or economic advantage. Though activated carbon is the most popular and widely used dye 
sorbent it has certain problems in its usage. The major drawback is its cost. Hence, there is a widespread awareness in using low cost, easily available biomaterials for the adsorption of dye colours. Many botanical materials of a very low price have directly been used as sorbent for dye adsorption from waste water ${ }^{9-20}$. Since India is a developing nation and a large producer of synthetic textile dyes, novel and economical treatment technologies of dye waste water are the need of the hour.

In the present study, a marine alga which is commonly and abundantly available in the Bay of Kodiyakkarai coast namely, Enteromorpha was selected as an adsorbent for the removal of Malachite green from aqueous solution.

\section{Experimental}

Enteromorpha was collected from Kodiyakkarai coast in south east coast of India and sun dried. Dry biomass was cut with a knife into irregular shaped particles between 1 and $3 \mathrm{~mm}$ in size. The biomass was then washed with distilled water, filtered and finally dried overnight at $60{ }^{\circ} \mathrm{C}$ and crushed to an average size of 0-63 $\mu$ in a mortar and then activated by $0.1 \mathrm{M} \mathrm{H}_{2} \mathrm{SO}_{4}$ for $24 \mathrm{~h}$ and finally carbonized and subsequently used for adsorption experiment.

\section{Adsorbate solution}

A $25 \mathrm{ppm}$ solution of malachite green dye was prepared by weighing accurately $25 \mathrm{mg}$ of analar grade malachite green dye and dissolving in $1000 \mathrm{~mL}$ standard flask. It was made up to the mark with deionised water. The stock solution was further diluted with deionised water to desired concentration for obtaining the test solution.

\section{Chemicals}

Analytical grade reagents were used for malachite green dye solution; ACS reagent grade concentrated hydrochloric acid, $\mathrm{NaOH}$ and $\mathrm{pH}$ buffer solutions were used to adjusted $\mathrm{pH}$ values of samples. In all experimental work, distilled demineralised water was used.

\section{Batch mode adsorption studies}

The adsorption of MG dye on the Enteromorpha was studied by batch technique. A known weight of adsorbent(for example 50-350 mg of adsorbent) was equilibrated with $50 \mathrm{~mL}$ of dye solution of known concentration in a $250 \mathrm{~mL}$ reagent bottle in a mechanical shaker for a known period of time( $30-180 \mathrm{~min}$ ). After equilibrium, the suspension of the adsorbent was separated from solution by filtration using Whatman no. 41 filter paper. The concentration of dye remaining in solution was measured. The effect of some parameters, such as $\mathrm{pH}$, concentrations, contact time and adsorbent dose on the adsorption was studied. The $\mathrm{pH}$ of the adsorptive solutions was adjusted using hydrochloric acid, sodium hydroxide and buffer solutions when required. The results of these studies were used to obtain the optimum conditions for maximum dye removal from aqueous solution.

\section{Results and Discussion}

The results of the experiments carried out for the removal of malachite green dye from aqueous solution using Enteromorpha as adsorbent are discussed below.

\section{Effect of initial concentration of dye}

The results for effect of initial concentration on percentage removal of dye using Enteromorpha is presented in Table 1. It can be seen from the Figure 1 that the percentage removal decreases with the increase in dye concentration. For Enteromorpha the percentage removal is $94.74 \%$ at the initial concentration of $25 \mathrm{mg} / \mathrm{L}$ for $250 \mathrm{mg}$ of adsorbent dose and a contact time of $3 \mathrm{~h}$. 
Table 1. Effect of initial concentration of MG dye using Enteromorpha at $120 \mathrm{~min}$

\begin{tabular}{ccc}
\hline S.No & Initial concentration $\mathrm{mg} / \mathrm{L}$ & \% removal of MG dye \\
\hline 1. & 5 & 100.0 \\
2. & 10 & 100.0 \\
3. & 15 & 92.60 \\
4. & 20 & 93.95 \\
5. & 25 & 84.2 \\
\hline
\end{tabular}

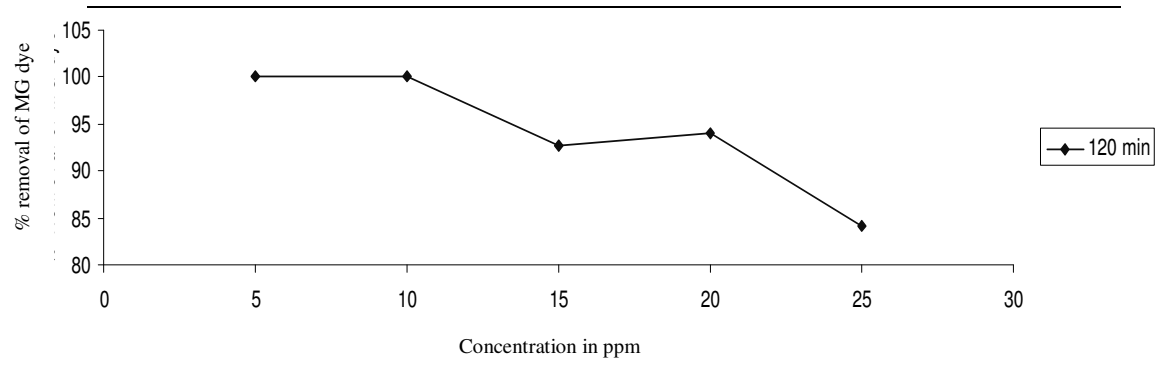

Figure 1.Effect of initial concentration on removal of MG dye

\section{Effect of adsorbent dose}

It is observed that there is a sharp increase in percentage removal with adsorbent dose for Enteromorpha. The results for adsorptive removal of MG dye with respect to adsorbent dose over the range of $50-350 \mathrm{mg}$ shown Table 2 and Figure 2 indicate that the percentage removal of dye increases with adsorbent dose. The increase in percentage removal is due to the greater availability of the exchangeable sites or surface area. Moreover, the percentage of dye adsorption on adsorbent is determined by the adsorption capacity of the adsorbents.

Table 2. Effect of adsorbent dosage on removal of MG dye (Initial concentration: $25 \mathrm{ppm}$ )

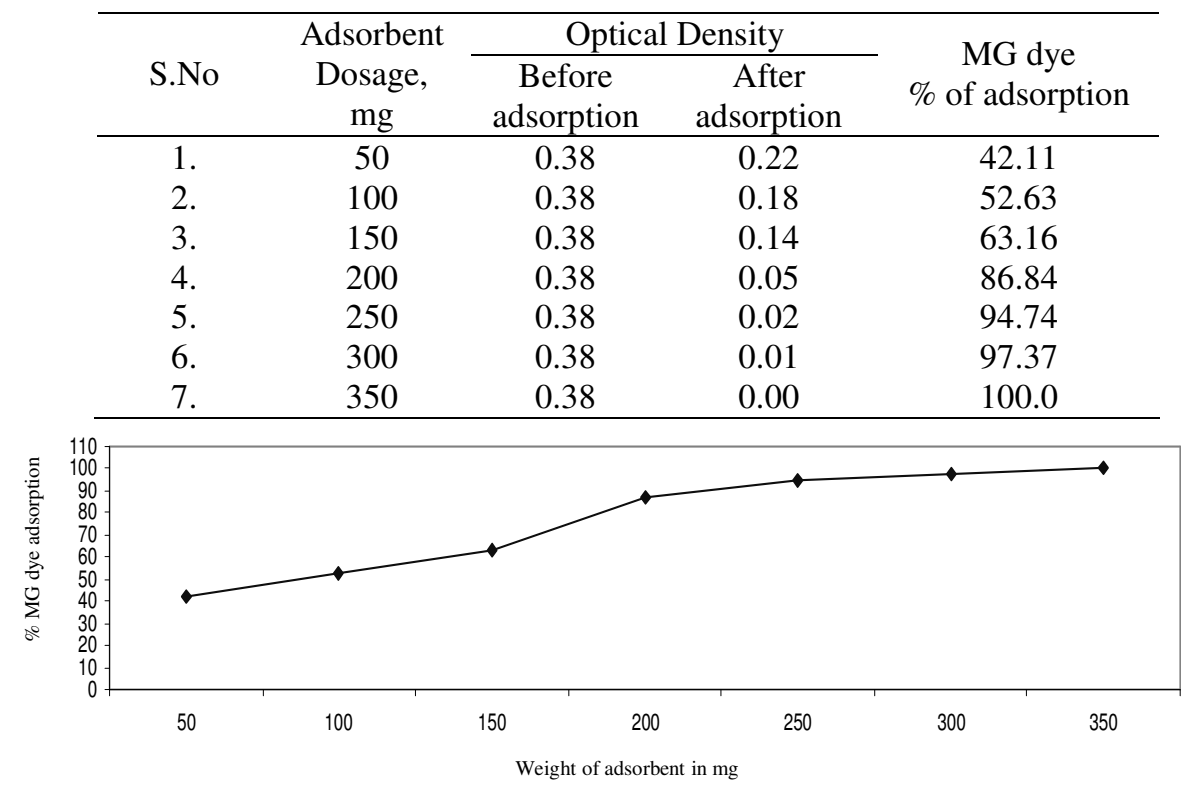

Figure 2. Effect of adsorbent dosage on removal of MG dye 


\section{Effect of contact time}

Figure 3 shows the variation in the percentage removal of MG dye with contact time on Enteromorpha. For varying initial dye concentration ranging from $5-25 \mathrm{mg} / \mathrm{L}$, Enteromorpha showed the percentage removal of $94.74 \%$ at the contact time of $3 \mathrm{~h}$. For the same concentration it was observed that the percentage removal was not increased with increase in contact time because equilibrium was attained. The optimal contact time to attain equilibrium with Enteromorpha was experimentally found to be about $3 \mathrm{~h}$.

Table 3. Effect of contact time on removal of MG dye (15 mg/L)

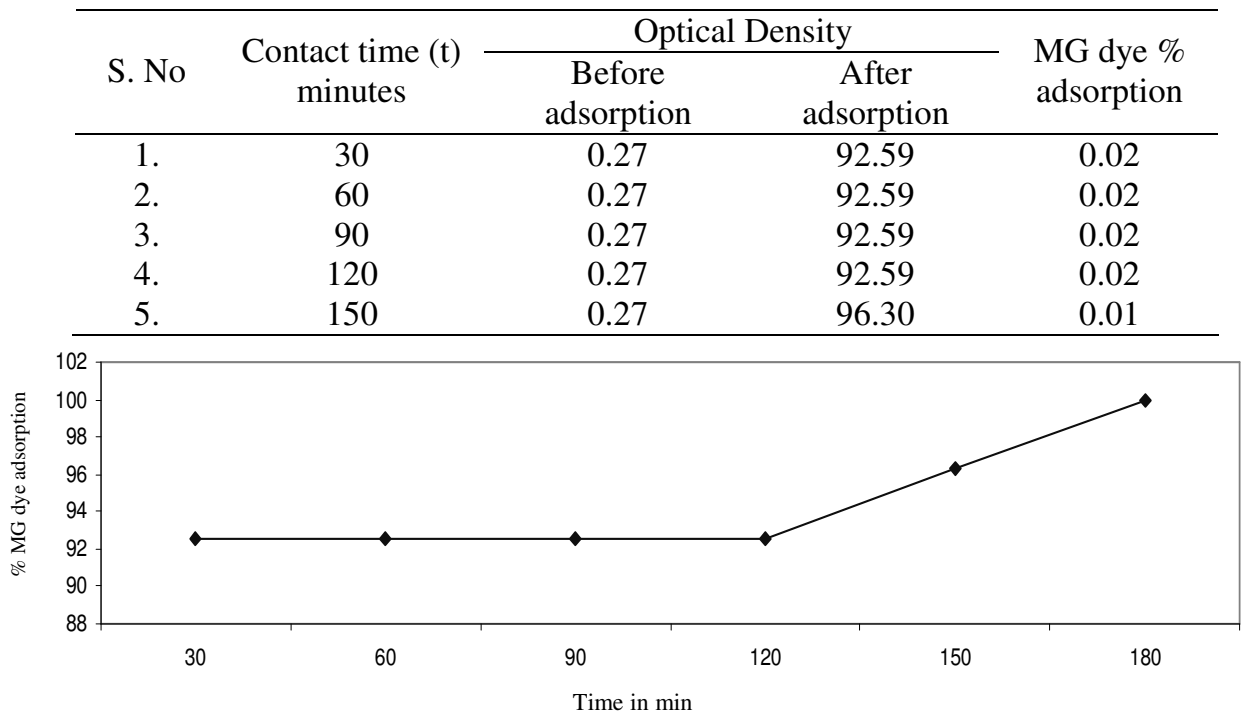

Figure 3. Effect of contact time on removal of MG dye (15 mg/L)

\section{Effect of $p H$}

The $\mathrm{pH}$ is one of the most important parameter controlling uptakes of dye from wastewater and aqueous solutions. The effect of $\mathrm{pH}$ on adsorption of dye on Enteromorpha was studied at room temperature by varying the $\mathrm{pH}$ of dye solution from 1-7. It can be observed from the results shown in Table 4 and Figure 4 that the removal of dye by Enteromorpha was maximum at $\mathrm{pH} 4$, other $\mathrm{pH}$ shows minimum adsorption.

Table 4. Effect of $\mathrm{pH}$ on removal of MG dye (contact time: $180 \mathrm{~min}$ )

\begin{tabular}{ccccc}
\hline & & \multicolumn{2}{c}{ Optical Density } & \multirow{2}{*}{$\begin{array}{c}\text { MG dye } \\
\text { S.No of }\end{array}$} \\
\cline { 3 - 4 } & pH & $\begin{array}{c}\text { Before } \\
\text { adsorption }\end{array}$ & $\begin{array}{c}\text { After } \\
\text { adsorption }\end{array}$ & $\begin{array}{c}\text { adsorption } \\
\text { adsorn }\end{array}$ \\
\hline 1. & 1 & 0.38 & 0.08 & 78.95 \\
2. & 2 & 0.38 & 0.07 & 81.58 \\
3. & 3 & 0.38 & 0.04 & 89.47 \\
4. & 4 & 0.38 & 0.02 & 94.74 \\
5. & 5 & 0.38 & 0.05 & 86.84 \\
6. & 6 & 0.38 & 0.04 & 89.47 \\
7. & 7 & 0.38 & 0.05 & 86.84 \\
\hline
\end{tabular}




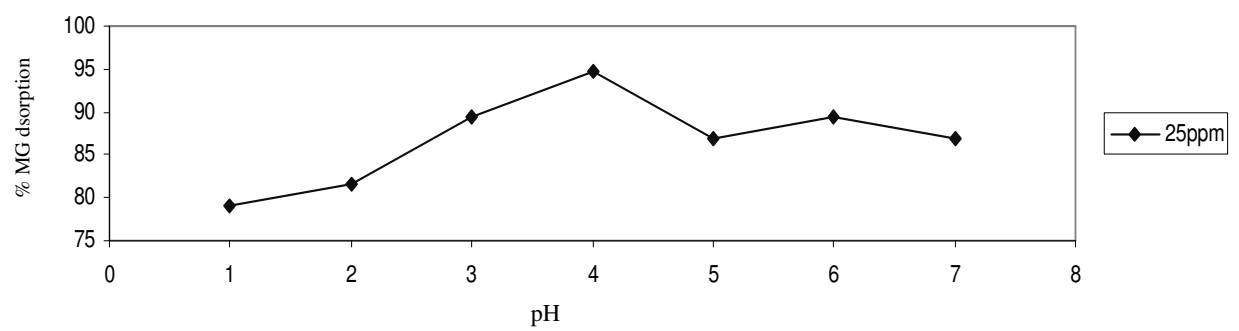

\section{Freundlich Isotherms}

Figure 4. Effect of $\mathrm{pH}$ on removal of $\mathrm{MG}$ dye

Freundlich isotherm is $\log \mathrm{q}_{\mathrm{e}}=\log \mathrm{K}_{\mathrm{f}}+1 / \mathrm{n} \log \mathrm{C}_{\mathrm{e}}$

Where qe is the amount of dye adsorbed per unit weight of adsorbent $(\mathrm{mg} / \mathrm{g}), \mathrm{K}_{\mathrm{f}}$ is the measure of sorption capacity and $1 / n$ is sorption intensity; $C_{e}$ is equilibrium concentration of residual dye in solution. Figure 5 shows the Freundlich adsorption isotherms for Enteromorpha. The straight line nature of the plots indicates that the process followed was of Freundlich adsorption type.

Table 5. Data for Freundlich plot (150 min)

\begin{tabular}{cccccccc}
\hline $\begin{array}{c}\text { S. } \\
\text { No. }\end{array}$ & $\begin{array}{c}\text { Initial } \\
\text { Concentration, } \\
\mathrm{mg} / \mathrm{L}\end{array}$ & $\begin{array}{c}\text { MG dye } \\
\text { eq, Ceq }\end{array}$ & $\log \mathrm{Ceq}$ & $\begin{array}{c}\text { MG dye } \\
\mathrm{ad}, \mathrm{x} \text { ' }\end{array}$ & $\begin{array}{c}\left(\frac{\mathrm{x}}{\mathrm{m}}\right), \mathrm{qe} \\
\mathrm{x} 10^{-5}\end{array}$ & $\begin{array}{c}\log _{\mathrm{e}} \\
\left(\frac{\mathrm{x}}{\mathrm{m}}\right)\end{array}$ & $\begin{array}{c}1+\log _{\mathrm{e}} \\
\left(\frac{\mathrm{x}}{\mathrm{m}}\right)\end{array}$ \\
\hline 1. & 5 & 0.00 & 0.00 & 5.00 & 0.500 & -0.30 & 0.70 \\
2. & 10 & 0.00 & 0.00 & 10.00 & 1.000 & 0.00 & 1.00 \\
3. & 15 & 0.55 & -0.26 & 14.45 & 1.445 & 0.16 & 1.16 \\
4. & 20 & 1.21 & 0.08 & 18.79 & 1.879 & 0.27 & 1.27 \\
5. & 25 & 0.66 & -0.18 & 23.03 & 2.303 & 0.32 & 1.32 \\
\hline
\end{tabular}

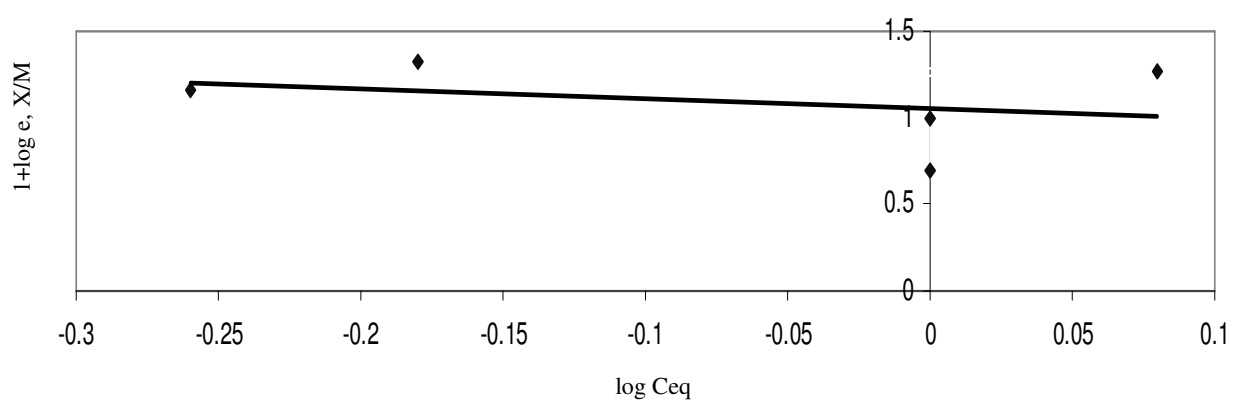

\section{Langmuir isotherm}

Figure 5. Data for Freundlich plot (150 min)

It is represented experimentally by the expression. $\frac{\mathrm{P}}{\mathrm{x} / \mathrm{m}}=\frac{1}{\mathrm{~K}_{1} \mathrm{~K}_{2}}+\frac{\mathrm{P}}{\mathrm{K}_{2}}$ where $\mathrm{K}_{1}$ and $\mathrm{K}_{2}$ are proportionality constants, $\mathrm{P}$ - initial concentration (Ceq), $\mathrm{x} / \mathrm{m}$ - amount of dye adsorbed at equilibrium (mg/g), qe. A plot of Ce/qe versus Ce will give a straight line. The slope of this is $1 / \mathrm{K}_{2}$ and intercept on the $\mathrm{y}-$ axis will give $1 / \mathrm{K}_{1} \mathrm{~K}_{2}$. Figure 6 indicates adsorption of dye on Enteromorpha is best fit with Langmuir model and so we infer that it followed Langmuir adsorption isotherms. 
Table 6. Data for Langmuir plot (120 min)

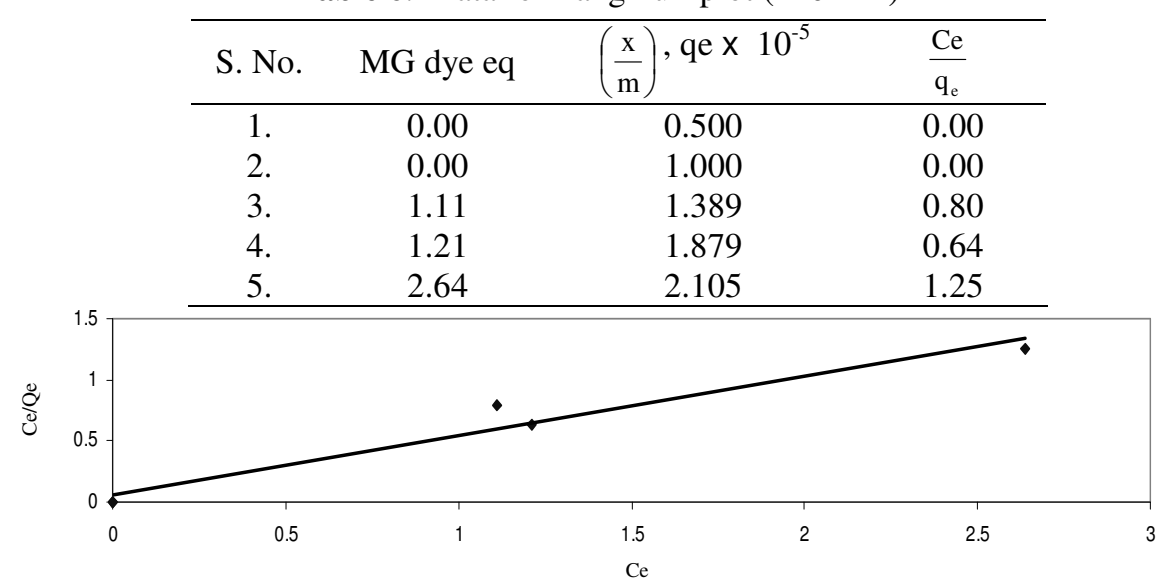

\section{Lagergren kinetics}

Figure 6. Data for Langmuir plot (120 min)

Lagergren also proposed kinetics for the adsorption. According to him, if a plot of time in minutes versus $\log _{10}\left(\mathrm{q}_{\mathrm{e}-\mathrm{q}}\right)$ gives a straight line and it follows the first order kinetics. If a plot of time in minutes versus $\mathrm{t} / \mathrm{q}$ gives a straight line and it follows the pseudo second order kinetics.

Where,

$$
\begin{aligned}
& \mathrm{q}_{\mathrm{e}}-\text { Maximum } x / m \text { value at maximum time } \\
& \mathrm{q} \text {-minimum } x / m \text { value at minimum time } \\
& \mathrm{x} \text {-amount of dye adsorbed } \\
& \mathrm{m} \text {-Mass of the adsorbent }
\end{aligned}
$$

\begin{tabular}{|c|c|c|c|c|c|}
\hline S. No & $\begin{array}{l}\text { Contact time } \\
\text { (t) minutes }\end{array}$ & MG dye ad ' $X$ ' $\mu \mathrm{g}$ & $\left(\frac{x}{m}\right)^{q \times 10^{-5}}$ & $\mathrm{q}_{\mathrm{e}}-\mathrm{q}$ & $t / q$ \\
\hline 1. & 30 & 16.36 & 1.636 & 0.364 & 18.34 \\
\hline 2. & 60 & 17.58 & 1.758 & 0.242 & 34.13 \\
\hline 3. & 90 & 18.18 & 1.818 & 0.182 & 49.50 \\
\hline 4. & 120 & 18.79 & 1.879 & 0.121 & 63.86 \\
\hline 5. & 150 & 18.79 & 1.879 & 0.121 & 79.83 \\
\hline 6. & 180 & 20.00 & 2.000 & 0.000 & 90.00 \\
\hline \multicolumn{6}{|c|}{$\left.5 \quad \begin{array}{r}100 \\
80 \\
60 \\
40 \\
20 \\
0\end{array}\right]$} \\
\hline & $\begin{array}{r}0+ \\
0\end{array}$ & 100 & 150 & 200 & \\
\hline
\end{tabular}

Figure 7 indicated adsorption of dye on Enteromorpha gave the straight line, so it followed the pseudo second order.

Table 7. Data for Lagergren plot $(20 \mathrm{mg} / \mathrm{L})$

Figure 7. Data for Lagergren plot $(20 \mathrm{mg} / \mathrm{L})$ 
XRD study

Further, the $\mathrm{x}$-ray diffraction studies of the carbon prepared from the marine algae Enteromorpha were carried out using Rotoflux x-ray diffractometer 20KW / 20A, Model 10.61 with a microprocessor record. The XRD pattern of the carbonized marine algae is shown in the Figure 8.

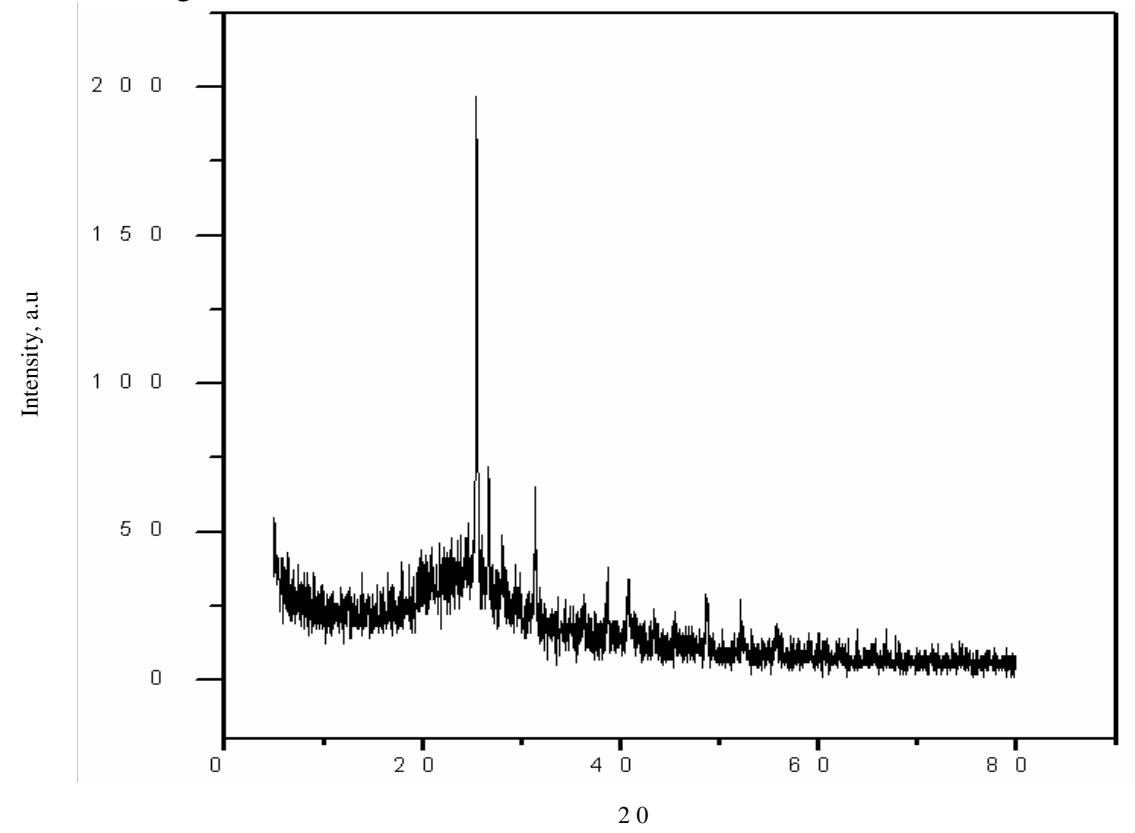

IR study

Figure 8. XRD Pattern of Enteromorpha

Fourier transform infrared spectroscopy (FTIR) was used to determine the vibration frequency changes in the functional groups of carbons. The spectra of carbon were measured within the range of $400-4000 / \mathrm{cm}$ wave number. Some fundamental FTIR frequencies of Enteromorpha observed for before and after adsorption are presented in Table 8. As can be inferred from Figure 8 that the adsorption frequencies are shifted to higher wave numbers with the adsorption of MG dye in Enteromorpha. From these findings it is presumed that the dye is incorporated within the adsorbent through interaction with the active functional groups.

Table 8. Some fundamental FTIR frequencies of Enteromorpha before and after adsorption

\begin{tabular}{ccc}
\hline Possible assignments & $\begin{array}{c}\text { Before adsorption } \\
\text { of Enteromorpha }\end{array}$ & $\begin{array}{c}\text { After adsorption of } \\
\text { Enteromorpha }\end{array}$ \\
\hline O-H stretching & 3412.08 & 3500 \\
C-H stretching & 2924.09 & 3000 \\
Quadrant \& semi-circle stretching & 1597.06 & 1600 \\
C-H in plane ring bending & 1099.43 & 1100 \\
N-H bending & 796.60 & 800 \\
C-I Stretching & 468.70 & 500 \\
\hline
\end{tabular}



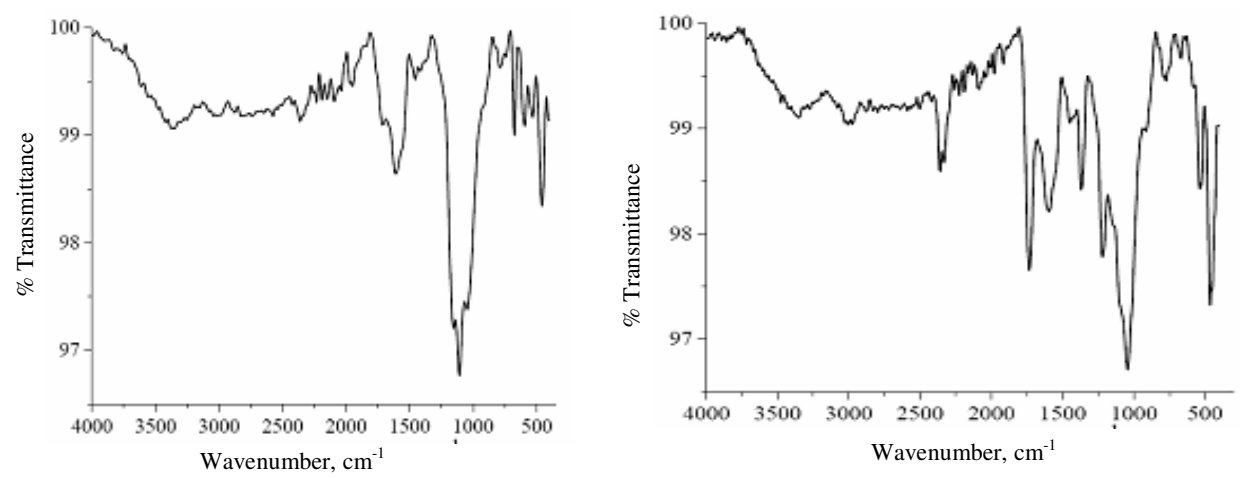

Figure 9. FTIR Spectrum of Enteromorpha before and after MG dye adsorption

\section{Conclusion}

The present study showed that Enteromorpha can be used as an effective adsorbent for the removal of Malachite green dye from aqueous solution. The maximum adsorption capacity was obtained (94.74\%) by using carbonaceous Enteromorpha at pH 4 with adsorbent dose of $250 \mathrm{mg}$ and with agitation time of 180 minutes .The adsorption followed pseudo second order kinetics and data fitted the Langmuir and Freundlich adsorption isotherms. The data may be useful in designing and fabrication of an economic treatment plant for the removal of Malachite green dye from wastewaters.

\section{References}

1. Seshadri S, Bishop P L and Agha A M, Waste Manage., 1994, 15, 127-137.

2. Nigam P. Armour G, Banat I M,Singh D and Marchant R, Biores Technol., 2000, 72, 219-226.

3. Chen K C, Wu J Y, Huang C C, Liang Y M and Hwang S C J, J Biotechnol., 2003, 101, 241-252.

4. $\quad$ Panswed J and Wongehaisuwan S, Water Sci Technol., 1986, 18, 139-144.

5. Malik P K and Saha S K, Sep Purif Technol., 2003, 31, 241-250.

6. Koch M, Yediler A, Leinert D, Insel G and Kettrup A, Chemosphere, 2002, 46, 109-113.

7. Ciardelli G, Corsi L and Marucci M, Resour Conserv Recy., 2000, 31, 189-197.

8. Venkata R B and Sastray C A, Indian J Environ Prot., 1987, 7, 363-376.

9. Robinson T, Chandran B and Nigam P, Bioresour Technol., 2002, 85, 119-124.

10. Garg V K, Gupta R, Yadav A B and Kumar R, Bioresour Technol., 2003, 89, 121-124.

11. Bhattacharyya K G and Sarma A, Dyes and Pigments, 2003, 57, 211-222.

12. Aksu Z, Porcess Biochem., 2005, 40, 997-1025.

13. Fu Y and Vijayaraghavan T, Adv Environ Res., 2004, 7, 239-247.

14. Namasivayam C, Radhika R and Suba S, Waste Manage., 2001, 21, 381-387.

15. Annadurai G, Juang R and Lee D, J Hazard Mater., 2002, B92, 263-274.

16. Bhattacharyya K G and Sharma A, J Environ Manage., 2004, 71, 217-229. 


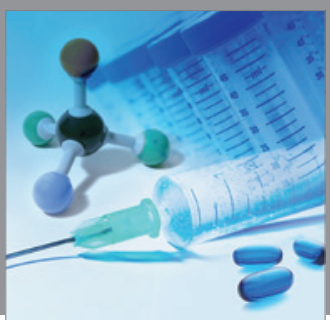

International Journal of

Medicinal Chemistry

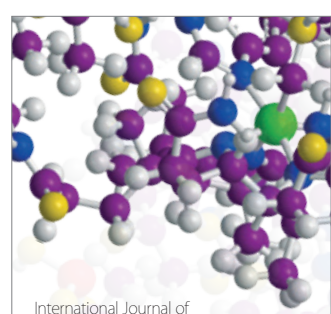

Carbohydrate Chemistry

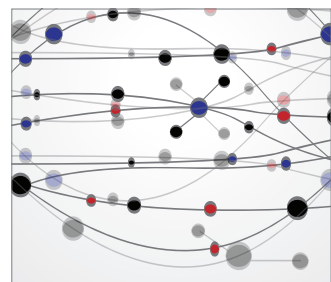

The Scientific World Journal
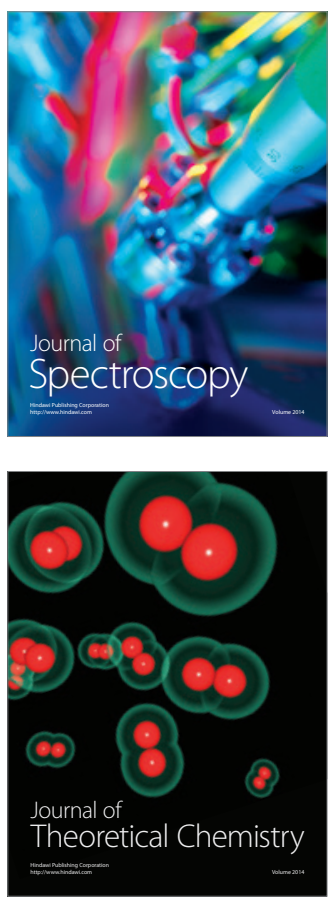
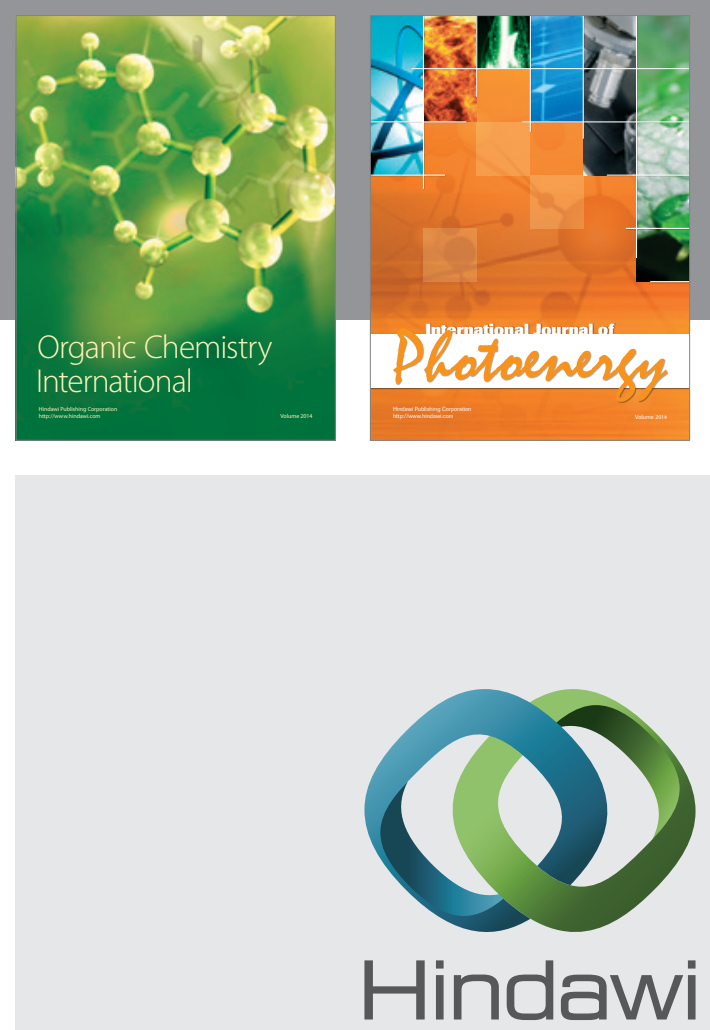

Submit your manuscripts at

http://www.hindawi.com
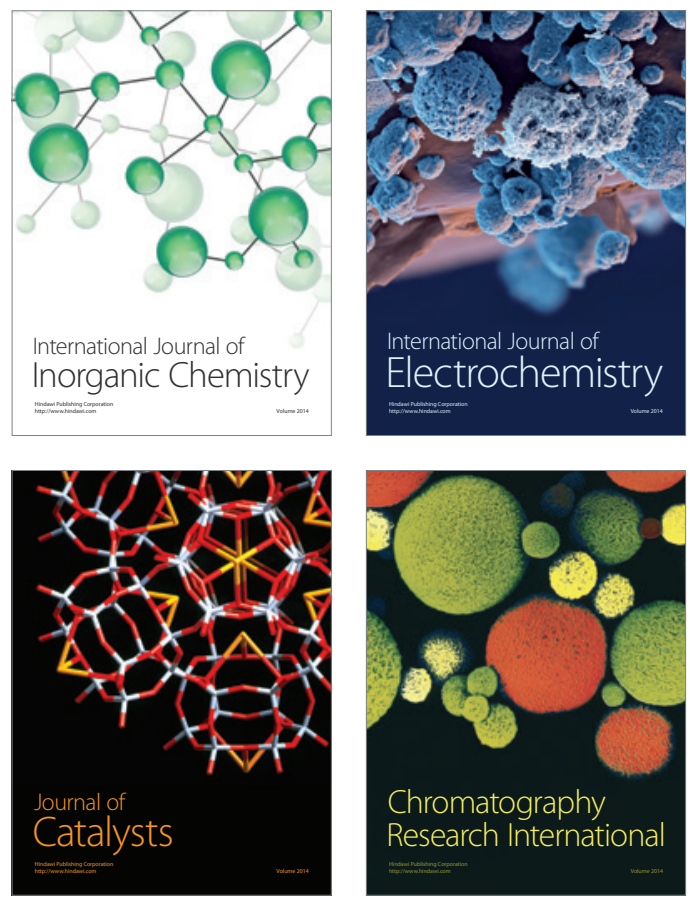
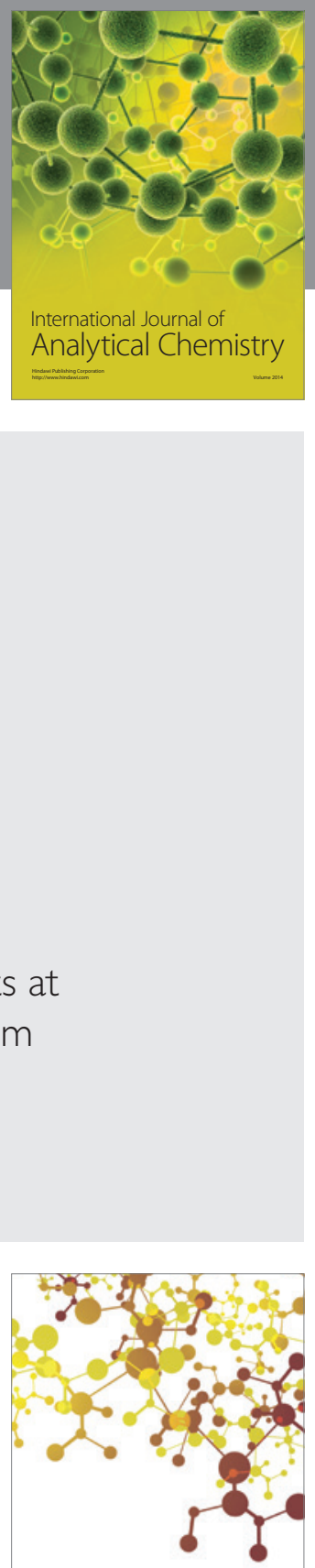

Journal of

Applied Chemistry
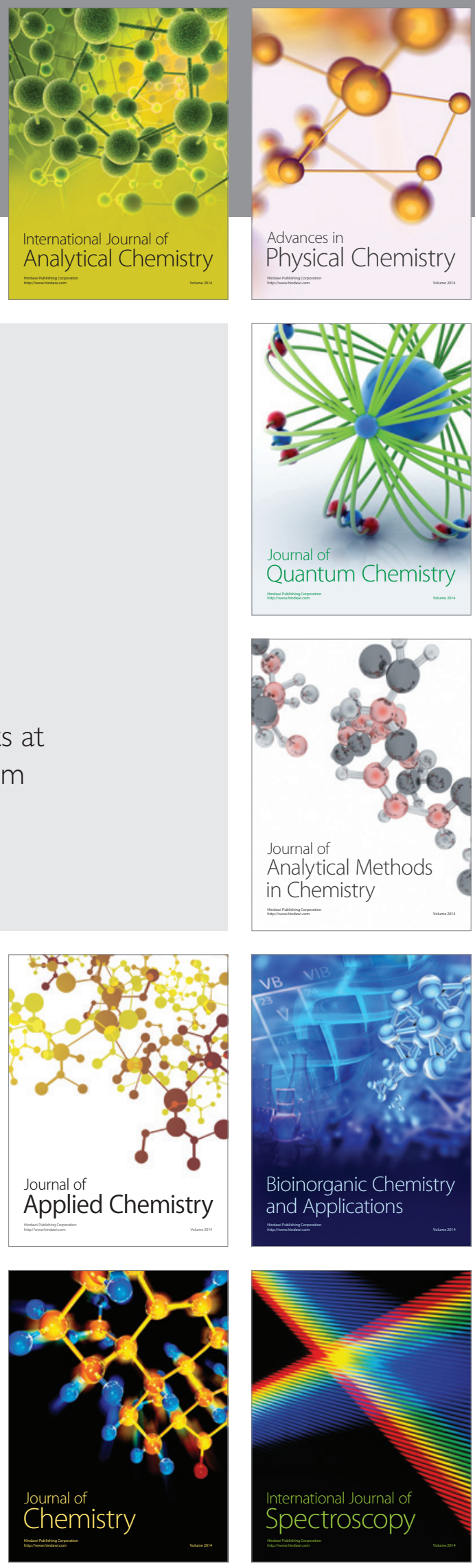